\title{
Shikonin enhances Adriamycin antitumor effects by inhibiting efflux pumps in A549 cells
}

\author{
XUCHUN LIU ${ }^{1,2}$ and GENGYUN SUN ${ }^{1}$ \\ ${ }^{1}$ Department of Respiratory Medicine, The First Affiliated Hospital of Anhui Medical University, Hefei, Anhui 230022; \\ ${ }^{2}$ Department of Respiratory Medicine, Chizhou Clinical College of Anhui Medical University, \\ Chizhou, Anhui 247000, P.R. China
}

Received December 13, 2015; Accepted May 18, 2017

DOI: $10.3892 / \mathrm{ol} .2017 .6702$

\begin{abstract}
Shikonin (SHK) is a natural naphthoquinone pigment isolated from Lithospermum erythrorhizon, that has been reported to suppress the growth of a number of cancer cell types. Adriamycin (AD) is typically used as an effective anticancer agent; however, it has the propensity to induce drug resistance. The aim of the present study was to investigate the effects of SHK alone and in combination with AD on lung adenocarcinoma cells and the underlying molecular mechanisms of their effects. Colony formation, MTT and propidium iodide staining assays demonstrated that the co-treatment of A549 cells with SHK and AD significantly decreased cell viability and potently induced apoptosis. The mitochondrial membrane potential was assessed using 5,5', 6,6'-tetrachloro-1,1',3,3'-tetraethyl-benzimidazolylcarbocyanine iodide staining and fluorescence microscopy. Cells co-treated with SHK and AD exhibited marked mitochondrial membrane damage. In addition, co-treatment with SHK and AD significantly reduced ATP levels in A549 cells compared with the control. Western blot analysis revealed that SHK enhanced the antitumor effects of AD by inhibiting the expression of ATP-binding cassette transporters. These results suggest that the inhibition of glycolysis could be an effective approach for lung cancer treatment. Therefore, SHK has the potential to be used as an anticancer agent in the treatment of lung adenocarcinoma, and thus warrants further investigation and development.
\end{abstract}

\section{Introduction}

Lung cancer is a major challenge to global public health due to its high epidemiologic incidence $(1,2)$. It is estimated that

Correspondence to: Professor Gengyun Sun, Department of Respiratory Medicine, The First Affiliated Hospital of Anhui Medical University, 218 Jixi Road, Shushan, Hefei, Anhui 230022, P.R. China

E-mail: gengyunsun@163.com

Key words: shikonin, Adriamycin, antitumor, efflux pump, A549 $\sim 1.8$ million patients are diagnosed with lung cancer annually, $80-85 \%$ of whom are diagnosed with non-small cell lung cancer (NSCLC), including squamous cell carcinoma, adenocarcinoma and large cell carcinoma (3-5).

Although there have been advances in treatment strategies, the survival rate for lung cancer remains low (6) Surgery is the most effective option for patients with lung cancer; however, in the majority of patients, lung cancer is diagnosed at the advanced stage, and only $30 \%$ of patients are eligible for curative resection (7) Therefore, chemotherapy and radiotherapy are considered as alternative options for these patients. However, modern chemotherapy using various antitumor drugs either incompletely kills the malignant cells or causes fatal dysfunction and serious systemic toxicity (8). In addition, tumor drug resistance is a major problem associated with chemotherapy and involves numerous factors, including anticancer drug potency, tumor cell-drug reaction, the tumor microenvironment and tumor cell heterogeneity (9). Numerous apoptosis-inducing agents are also substrates and inducers of drug transporters, including P-glycoprotein (P-gp), multidrug resistance-associated protein 1 (MRP1) and breast cancer resistance protein (BCRP) $(10,11)$. These drug transporters recognize numerous functionally and structurally independent anticancer drugs and, therefore, can expel intracellular drugs efficiently. The overexpression of these proteins can confer cancer cells with multidrug resistance $(12,13)$. The development of strategies to overcome the side effects and drug resistance of antitumor drugs is an ongoing challenge for medical workers. As a broad-spectrum anticancer drug, Adriamycin (AD) is used in chemotherapy to treat a variety of tumor types. However, in addition to bone marrow suppression, myocardial injury and other side effects, drug resistance is an important factor that limits its use (14). Furthermore, the efficacy of AD is associated with drug concentration, which is also associated with drug resistance. The inhibition of tumor cell efflux can effectively increase the sensitivity of tumor cells to chemotherapeutic drugs $(15,13)$. Therefore, agents with high efficacy and few side effects are urgently required in clinical practice.

A number of previous studies have aimed to extract and screen the active components of traditional Chinese herbs in order to develop effective and relatively safe drugs for cancer treatment $(16,17)$. Shikonin (SHK) is the major active ingredient 
isolated from the dried roots of Lithospermum erythrorhizon, and possesses a molecular weight of $288 \mathrm{kDa}$.

The anticancer effects of SHK have been investigated in numerous prior studies (18-24). SHK is not toxic to normal cells (25), but exerts cytotoxic effects against various neoplastic cells, and has not been demonstrated to promote anticancer drug resistance (26). However, its effects against lung cancer remain unclear. The aim of the present study was to investigate the effects of SHK on lung adenocarcinoma cells and the underlying molecular mechanisms of these effects, which may provide an understanding of its novel antitumor functions.

\section{Materials and methods}

Reagents. SHK was purchased from Shanghai Shifeng Biological Technology Co., Ltd. (Shanghai, China). AD was purchased from Zhejiang Hisun Chemical Co., Ltd. (Taizhou, China). MTT was purchased from Sigma-Aldrich (Merck KGaA, Darmstadt, Germany). The JC-1 and propidium iodide (PI) assay kits were purchased from Beyotime Institute of Biotechnology (Haimen, China), and the ATP assay kit was obtained from Sigma-Aldrich (Merck KGaA). Monoclonal antibodies against MRP-1 (cat. no. sc-13960) and $\beta$-actin were purchased from Santa Cruz Biotechnology, Inc. (Dallas, TX, USA). The anti-BCRP antibody (cat. no. MAB4155F) was obtained from EMD Millipore (Billerica, MA, USA) and the anti-P-gp antibody (cat. no. ab98322) was from Abcam (Cambridge, UK).

Cell lines and culture. The human A549 lung adenocarcinoma cancer cell line was obtained from the Central Laboratory of the Central South University (Changsha, China), and cultured in Dulbecco's modified Eagle's medium (Gibco; Thermo Fisher Scientific, Inc., Waltham, MA, USA) supplemented with $10 \%$ fetal bovine serum (FBS) without mycoplasma (Sigma-Aldrich; Merck KGaA), penicillin $(100 \mu \mathrm{g} / \mathrm{ml})$ and streptomycin $(100 \mu \mathrm{g} / \mathrm{ml}$; North China Pharmacy Co., Ltd., Shijiazhuang, China) at $37^{\circ} \mathrm{C}$ in a humidified incubator with $5 \% \mathrm{CO}_{2}$. The culture solution was replaced every 2 days, and cell morphology and vitality were monitored using an inverted microscope (Olympus Corporation, Tokyo, Japan).

Cell viability assay. A549 cells were counted using a cell counting plate prior to being seeded into 96 -well tissue culture plates at a density of $1 \times 10^{4}$ cells/well, and cultured at $37^{\circ} \mathrm{C}$ with $5 \% \mathrm{CO}_{2}$ overnight. Subsequently, the cells were exposed to various concentrations of SHK $(0.8,1.6,3.2,6.4,12.8$ or $25.6 \mu \mathrm{mol} / \mathrm{l})$ or $\mathrm{AD}(0.375,0.75,1.5,3,6$ or $12 \mathrm{mg} / \mathrm{l})$ and then cultured for 24 and $48 \mathrm{~h}$, respectively control cells were incubated with medium only. The cells were further incubated with PBS containing $5 \mathrm{mg} / \mathrm{ml}$ MTT for $4 \mathrm{~h}$ at $37^{\circ} \mathrm{C}$, then the MTT solution was removed and replaced with $150 \mu$ l dimethyl sulfoxide/well. Following this, the absorbance of the reaction solution was measured using a plate reader at $490 \mathrm{~nm}$.

Colony formation assays. A549 cells were seeded in 6-well plates at a density of $4 \times 10^{3}$ cells/well and treated with $1.6 \mu \mathrm{mol} / 1$ SHK, $0.75 \mathrm{mg} / \mathrm{l} \mathrm{AD}$ or both $(1.6 \mu \mathrm{mol} / 1 \mathrm{SHK}$ and $0.75 \mathrm{mg} / \mathrm{l} \mathrm{AD})$ for $24 \mathrm{~h}$. Following drug treatment, the cells were inoculated onto the 6-hole culture plate. The number of cells was adjusted

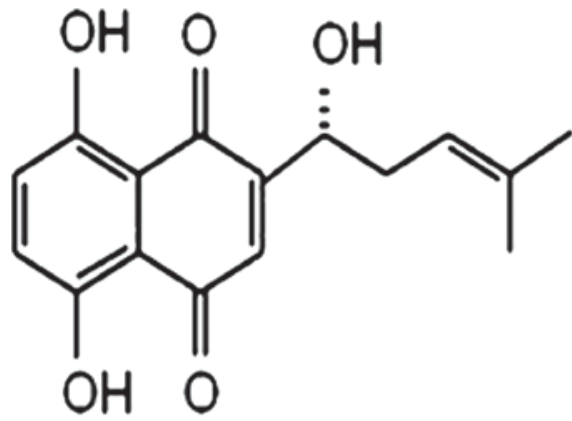

Figure 1. Chemical structure of shikonin.

to 100 cells/hole. The culture plate was placed in saturated humidity at $37^{\circ} \mathrm{C}$ and $5 \% \mathrm{CO}_{2}$ environment for 7 days. Following this, medium was removed and the plates were rinsed with PBS 2 times. Methanol was used to fix the plates for $15 \mathrm{~min}$ and air dried once the methanol was discarded. A total of $200 \mathrm{ml} /$ pore $0.5 \%$ crystal violet stain was added, and after $20 \mathrm{~min}$ at room temperature, the plates were rinsed under water to remove the dye solution. The colonies were visualized under an inverted microscope (Olympus Corporation, Tokyo, Japan), violet and the cell number was counted in 10 fields of view.

PI staining. A549 cells were cultured in 6-well plates $\left(2 \times 10^{6}\right.$ cells/well) for $24 \mathrm{~h}$ and allowed to attain exponential growth. Then the cells were treated with $1.6 \mu \mathrm{mol} / 1 \mathrm{SHK}$, $0.75 \mathrm{mg} / \mathrm{l} \mathrm{AD}$, or both for $24 \mathrm{~h}$, stained with $600 \mu \mathrm{l} \mathrm{PI} /$ well for $2 \mathrm{~h}$ and then evaluated using flow cytometry (Accuri C6: US; BD Biosciences, Franklin Lakes, NJ, USA). SPSS 19.0 (IBM Corp., Arkmonk, NY, USA) was used to analyse the results of the results.

Intracellular ATP measurement. A549 cells were seeded at $2 \times 10^{5}$ cells/well in a culture plate for $24 \mathrm{~h}$. Cellular ATP levels were determined using the CellTiter-Glo ${ }^{\circledR}$ Luminescent Cell Viability Assay kit (Promega Corporation, Madison, WI, USA), according to the manufacturer's protocol. The luminescence levels were measured using the luminometer mode on a microplate reader.

Mitochondrial membrane potential. A549 cells were cultured in 12-well plates at a density of $2 \times 10^{5}$ cells/well for $24 \mathrm{~h}$ and allowed to attain exponential growth prior to treatment. Changes in the mitochondrial membrane potential were evaluated using the JC-1 Mitochondrial Membrane Potential Fluorescence Probe kit (Nanjing KeyGen Biotech Co., Ltd., Nanjing, China) according to the manufacturer's protocol. The cells stained with JC-1 solution were visualized using an inverted fluorescence microscope (IX-71: Olympus Corporation).

Live cell imaging. A549 cells were cultured in 6-well plates ( $2 \times 10^{5}$ cells/well) for $24 \mathrm{~h}$ to allow attainment of exponential growth. Then, the cells were treated with $1.6 \mu \mathrm{mol} / 1 \mathrm{SHK}$ followed by $0.75 \mathrm{mg} / \mathrm{l} \mathrm{AD}$ for $1 \mathrm{~h}$ each. The drug-induced fluorescence in the cells was visualized using a live cell imaging system (Olympus Corporation Live Cell Imaging Workstation IX83). 
A

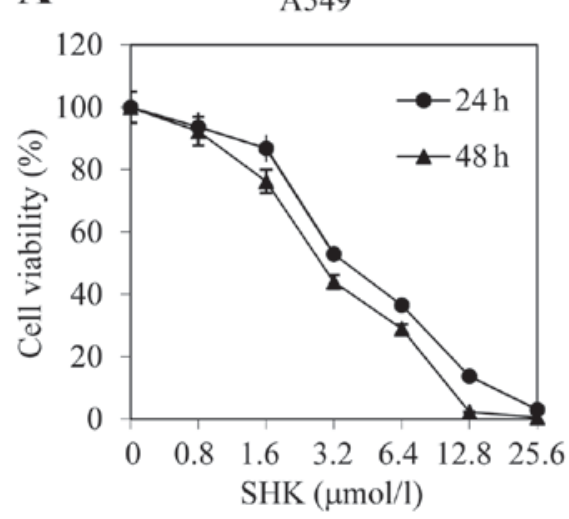

B

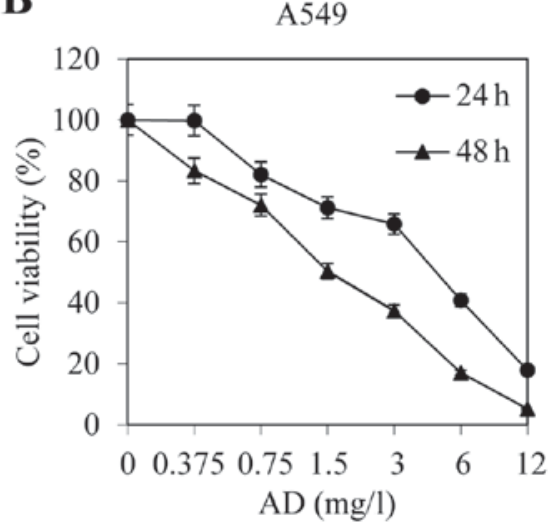

Figure 2. SHK and AD exhibit cytotoxic effects in A549 cells. A549 cells were treated with (A) SHK (0.8, 1.6, 3.2, 6.4,12.8 or 25.6 $\mu$ mol/1) or (B) AD (0.375, $0.75,1.5,3,6$ or $12 \mathrm{mg} / \mathrm{l})$ for 24 and $48 \mathrm{~h}$, respectively. Cell viability was analyzed using an MTT assay. Data are presented as the mean \pm standard error of the mean of 4 independent experiments. SHK, shikonin; AD, Adriamycin.
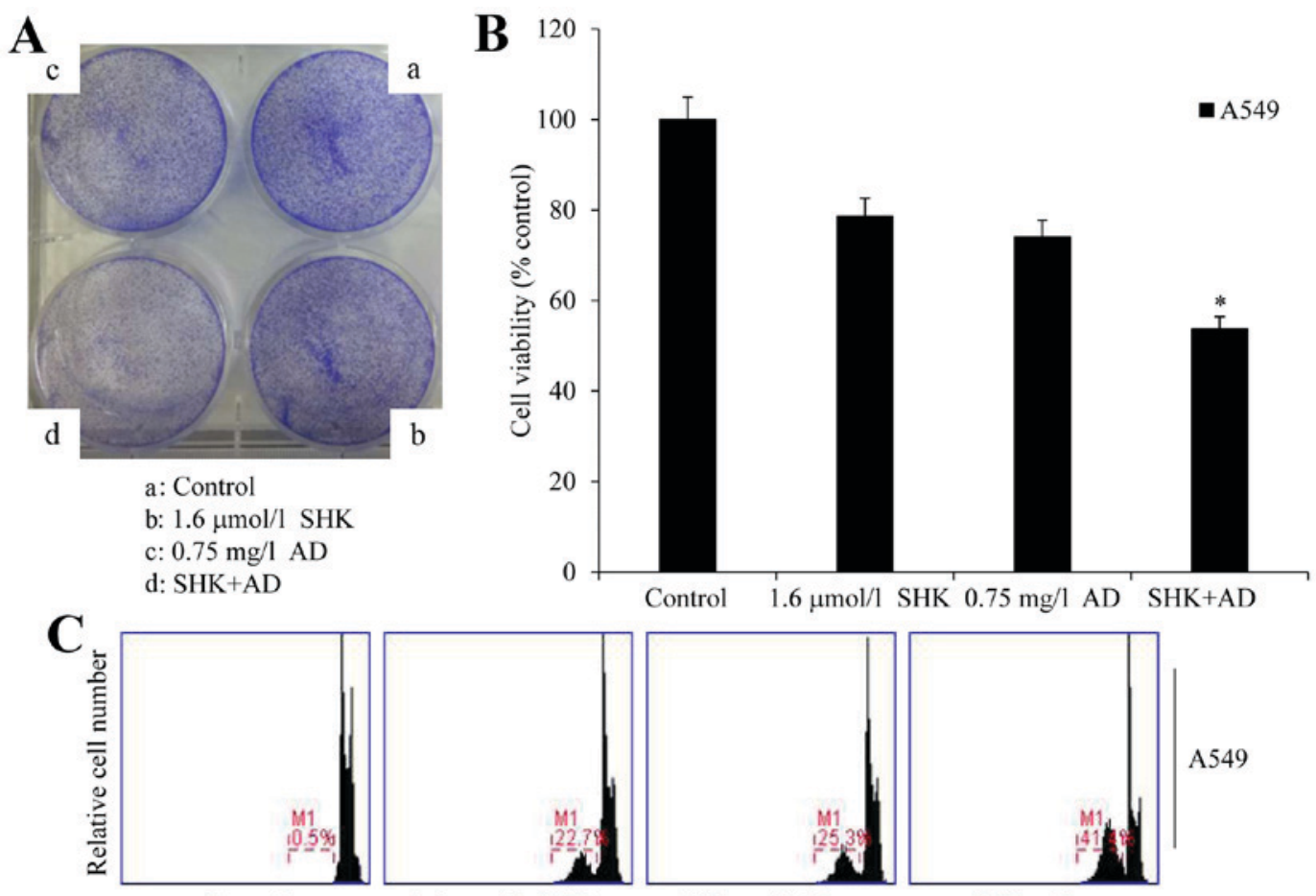

Control

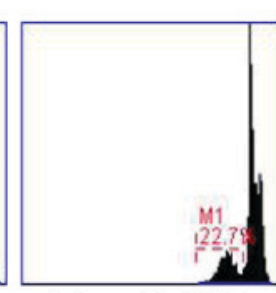

$1.6 \mu \mathrm{mol} / \mathrm{L} \mathrm{SHK}$

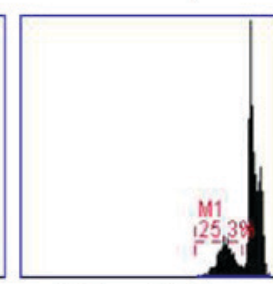

$0.75 \mathrm{mg} / \mathrm{L} \mathrm{AD}$

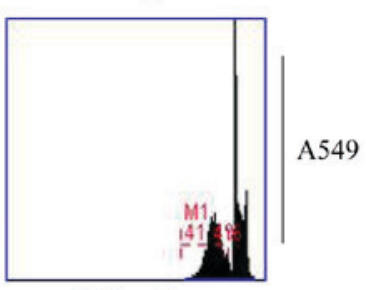

$\mathrm{SHK}+\mathrm{AD}$

Figure 3. SHK sensitizes A549 cells to AD-induced cell growth inhibition and apoptosis. (A) A549 cells were treated with the control, SHK (1.6 $\mu$ mol/1), AD $(0.75 \mathrm{mg} / \mathrm{l})$ or SHK $(1.6 \mu \mathrm{mol} / \mathrm{l})+\mathrm{AD}(0.75 \mathrm{mg} / \mathrm{l})$ for 7 days. Cell viability was determined using crystal violet staining. (B) A549 cells were treated with SHK $(1.6 \mu \mathrm{mol} / \mathrm{l}), \mathrm{AD}(0.75 \mathrm{mg} / \mathrm{l})$ or SHK $(1.6 \mu \mathrm{mol} / \mathrm{l})+\mathrm{AD}(0.75 \mathrm{mg} / \mathrm{l})$ for $24 \mathrm{~h}$, and cell viability was assessed using an MTT assay. Data are presented as the mean \pm standard error of the mean of 4 independent experiments. "P<0.01 vs. the control. (C) A549 cells were treated with SHK (1.6 $\mu \mathrm{mol} / \mathrm{l}), \mathrm{AD}(0.75 \mathrm{mg} / \mathrm{l})$ or SHK $(1.6 \mu \mathrm{mol} / \mathrm{l})+\mathrm{AD}(0.75 \mathrm{mg} / \mathrm{l})$ for $24 \mathrm{~h}$, prior to being analyzed using flow cytometry. SHK, shikonin; AD, Adriamycin.

Western blot analysis. A549 cells were rinsed with ice-cold PBS and lysed with radioimmunoassay precipitation buffer (Shanghai Fankang Biotechnology Co., Ltd., Shanghai, China) for $30 \mathrm{~min}$ on ice. The cell lysates were centrifuged at $12,000 \mathrm{x} \mathrm{g}$ for $30 \mathrm{~min}$ at $4^{\circ} \mathrm{C}$. The supernatant proteins were separated using 6\% SDS-PAGE and subsequently transferred to PVDF membranes (Bio-Rad Laboratories, Inc., Hercules, CA, USA). The membranes were blocked with $5 \%$ skimmed milk + TBST for $1 \mathrm{~h}$ at room temperature, and then washed with TBST 3 times. Membranes were then incubated with primary antibodies overnight at $4^{\circ} \mathrm{C}$, followed by the horseradish peroxidase-labeled rabbit anti-mouse $\operatorname{IgG}$ (cat. no. PA128568; Invitrogen; Thermo Fisher Scientific, Inc.), while $\beta$-actin was used as the loading control. TBST was used to rinse the polyvinylidene fluoride (PVDF) membranes 3 times for $10 \mathrm{~min}$ each time. The PVDF membranes were dipped in methanol for $10 \mathrm{~min}$, and the membranes were allowed to develop in the dark. Following this, the membranes were analyzed using an BIO-RAD gel imaging system (Bio-Rad Technologies, Inc., Hercules, CA, USA). A gel band image analysis system was used to analyze the electrophoresis band density with Quantity One version 4.6.6 software (Bio-Rad Technologies, Inc.), and 


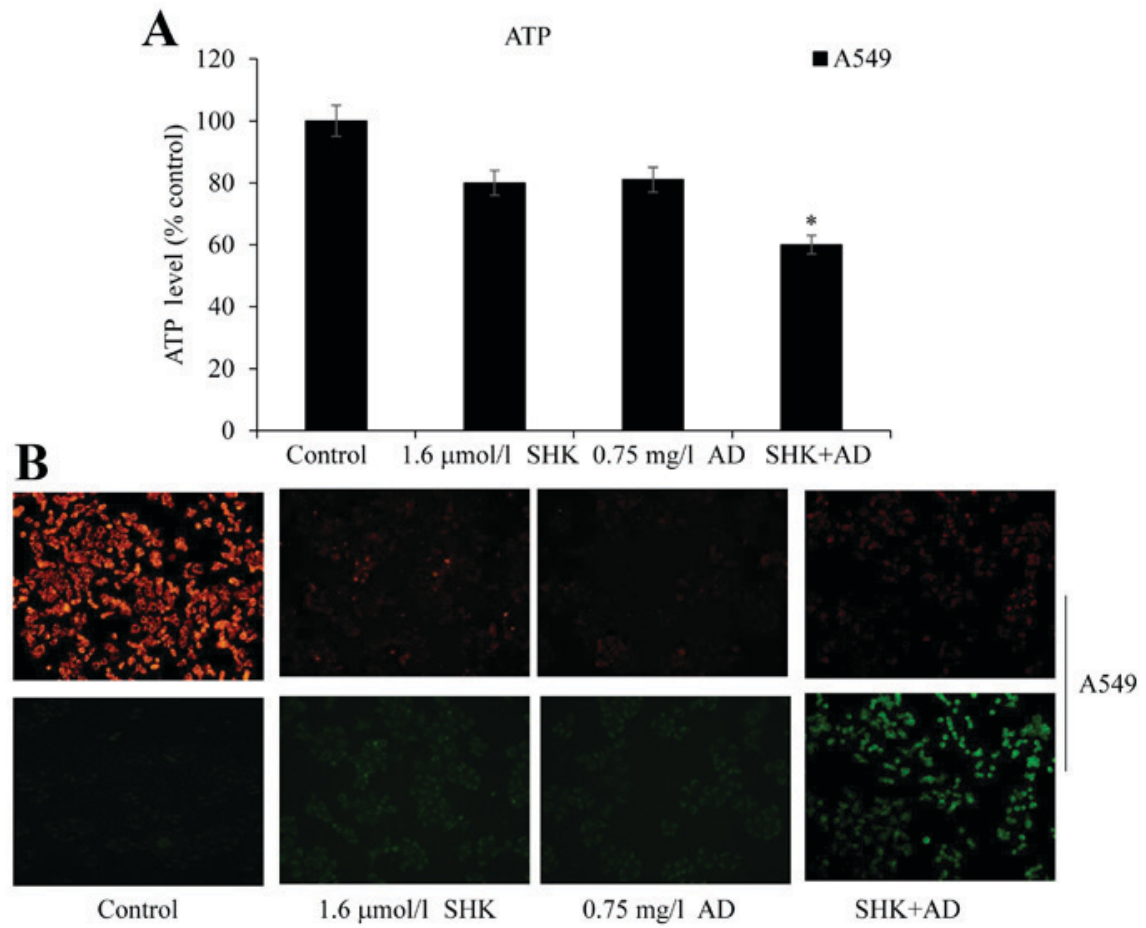

Figure 4. SHK disrupts the mitochondrial membrane potential and inhibits ATP generation in A549 cells. (A) Intracellular ATP levels were evaluated in A549 cells treated with SHK $(1.6 \mu \mathrm{mol} / \mathrm{l}), \mathrm{AD}(0.75 \mathrm{mg} / \mathrm{l})$ or SHK $(1.6 \mu \mathrm{mol} / \mathrm{l})+\mathrm{AD}(0.75 \mathrm{mg} / \mathrm{l})$ for $5 \mathrm{~h}$. Data are presented as the mean \pm standard error of the mean of 3 independent experiments. "P $<0.05$ vs. the control. (B) A549 cells were treated with indicated concentrations of SHK (1.6 $\mu \mathrm{mol} / \mathrm{l})$, AD (0.75 mg/l) or SHK $(1.6 \mu \mathrm{mol} / \mathrm{l})+\mathrm{AD}(0.75 \mathrm{mg} / \mathrm{l})$ for $24 \mathrm{~h}$, and the mitochondrial membrane potential was assessed using JC-1 staining and fluorescence microscopy (magnification, x200). When mitochondrial membrane potential is intact, cells fluoresce red. In contrast, when it is destroyed, cells fluoresce green. SHK, shikonin; AD, Adriamycin.

the ratio of target protein band density and internal reference band optical density was used as the relative expression for each group of proteins.

Statistical analysis. All statistical analyses were performed using an unpaired Student's t-test or an analysis of variance followed by the Student-Newman-Keuls test in SPSS 19.0 (IBM Corp., Armonk, NY, USA). $\mathrm{P}<0.05$ was considered to indicate a statistically significant difference.

\section{Results}

SHK and AD induce cytotoxicity in A549 cells. The chemical structure of SHK is illustrated in Fig. 1. To investigate the cytotoxicity of SHK and AD, A549 cells were treated with various concentrations of the agents for 24 and $48 \mathrm{~h}$, respectively. The MTT assay results revealed that SHK and AD each significantly decreased the viability of A549 cells in a dose-dependent manner compared with the control group (Fig. 2A and B).

SHK sensitizes A549 cells to AD-induced cell growth inhibition and apoptosis. To determine whether SHK sensitized A549 cells to chemotherapeutic agents, cells were co-treated with AD and SHK. Colony formation, MTT and PI staining assays demonstrated that SHK administered in combination with AD significantly decreased cell viability when compared with the control group and with the cells treated with SHK or AD alone $(\mathrm{P}<0.01)$, and also potently induced the apoptosis of A549 cells (Fig. 3A-C). The survival rate of the cells treated with SHK and AD was $53.77 \%$, which was statistically different from that of the single treatment groups, at $78.68 \%$ for $\mathrm{SHK}$ and $74.07 \%$ for $\mathrm{AD}(\mathrm{P}<0.01)$. These results suggest that SHK sensitizes A549 cells to AD-induced cell growth inhibition and apoptosis.

SHK damages the mitochondrial membrane potential and inhibits ATP generation in A549 cells. Mitochondrial membrane potential loss and the consequent production of reactive oxygen species (ROS) are the common landmark events of early apoptosis (27). ROS interact with mitochondrial antioxidants and induce apoptosis by releasing cytochrome $c$ from the mitochondria. Furthermore, ROS inhibit the production of ATP, which in turn further increases apoptosis and ROS generation $(28,27)$. Treatment of A549 cells with SHK or AD alone did not significantly decrease ATP levels compared with the control group; however, co-treatment with SHK and AD significantly decreased ATP levels in the A549 cells when compared with the control ( $\mathrm{P}<0.05$; Fig. 4A). To further assess changes in mitochondrial membrane potential, JC-1 was used as a fluorescent marker. When the mitochondrial membrane potential is intact the cells fluoresce red, whereas cell dysfunction induces a green fluorescence (29). SHK-treated and SHK/AD co-treated A549 cells exhibited clear mitochondrial membrane potential damage with green fluorescence following JC-1 staining; the co-treated cells exhibited a bright green fluorescence and the control cells exhibited a bright red fluorescence (Fig. 4B). Taken together, these results suggest that SHK adversely affects the mitochondrial membrane potential and decreases ATP generation in A549 cells. 


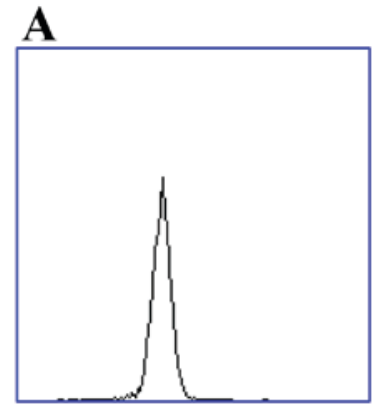

Control

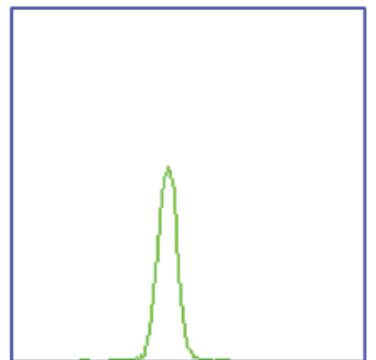

$0.75 \mathrm{mg} / \mathrm{l} \mathrm{AD}$

Control

$0.75 \mathrm{mg} / \mathrm{l} \mathrm{AD}$

$1.6 \mu \mathrm{mol} / 1 \mathrm{SHK}+0.75 \mathrm{mg} / \mathrm{l} \mathrm{AD}$

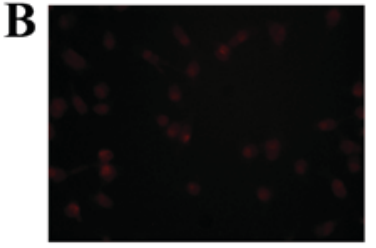

Control

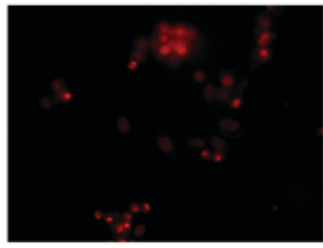

$0.75 \mathrm{mg} / \mathrm{l} \mathrm{AD} \quad 1.6 \mu \mathrm{mol} / 1 \mathrm{SHK}+0.75 \mathrm{mg} / \mathrm{l} \mathrm{AD}$

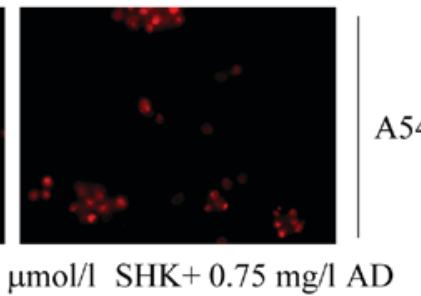

Figure 5. SHK enhances AD accumulation and reduces efflux from A549 cells. (A) A549 cells were cultured in the presence or absence of SHK (1.6 $\mu$ mol/1); $30 \mathrm{~min}$ later, $\mathrm{AD}(0.75 \mathrm{mg} / \mathrm{l})$ was added and the intracellular fluorescence levels were analyzed by flow cytometry following incubation for 30 min. Then the cells were further incubated in the presence or absence of SHK $(1.6 \mu \mathrm{mol} / \mathrm{l})$ for $1 \mathrm{~h}$, and intracellular fluorescence levels were analyzed by flow cytometry. (B) A549 cells were treated with SHK (1.6 $\mu \mathrm{mol} / \mathrm{l})$, AD $(0.75 \mathrm{mg} / 1)$ or SHK $(1.6 \mu \mathrm{mol} / \mathrm{l})+\mathrm{AD}(0.75 \mathrm{mg} / \mathrm{l})$ for $24 \mathrm{~h}$, and cell fluorescence was detected using a live cell imaging system (magnification, x200). SHK, shikonin; AD, Adriamycin.

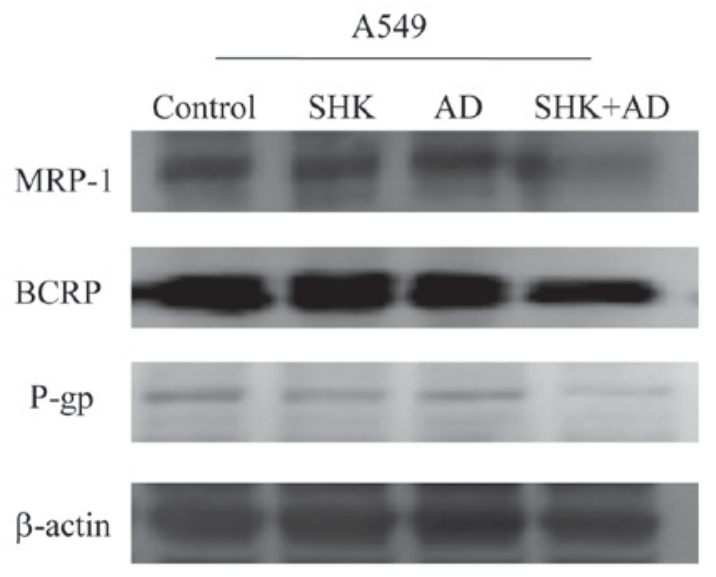

Figure 6. SHK enhances the antitumor effects of AD by inhibiting ABC transporter expression. A549 cells were treated with the indicated concentrations of SHK $(1.6 \mu \mathrm{mol} / 1)$, AD $(0.75 \mathrm{mg} / 1)$ or SHK $(1.6 \mu \mathrm{mol} / 1)+$ AD $(0.75 \mathrm{mg} / \mathrm{l})$ for $24 \mathrm{~h}$. At the end of each treatment, total cell lysates were subjected to western blot analysis. The expression of MRP-1, BCRP and P-gp was monitored. SHK, shikonin; AD, Adriamycin; MRP-1, multidrug resistance-associated protein 1; BCRP, breast cancer resistance protein; P-gp, P-glycoprotein.

SHK enhances AD accumulation and reduces efflux in A549 cells. The anticancer activity of SHK, as well as inhibition of the cellular efflux of $\mathrm{AD}$, requires depletion of the cellular ATP pool as the ATP-binding cassette $(\mathrm{ABC})$ transporters are ATP-dependent (30). To assess whether SHK enhanced AD accumulation through reduced ATP production, the effects of glycolysis inhibition on AD accumulation and efflux were evaluated in A549 cells. Flow cytometry analysis revealed that
SHK markedly increased intracellular AD levels in A549 cells (Fig. 5A); a similar result was obtained using a live imaging system (Fig. 5B). These results collectively suggest that SHK enhances AD accumulation and reduces efflux partly by reducing ATP levels in A549 cells.

SHK enhances the antitumor effects of $A D$ by inhibiting $A B C$ transporter expression. To confirm the effect of ATP reduction in A549 cells, the expression of MRP1, BCRP and P-gp was analyzed in A549 cells. Co-treatment with SHK and $\mathrm{AD}$ resulted in a marked decrease in MRP1, BCRP and P-gp expression when compared with the control and either treatment administered alone (Fig. 6).

\section{Discussion}

Multi-drug resistance (MDR) constitutes a unique and critical spectrum of drug resistance $(21,31)$ with serious therapeutic consequences. MDR development is typically associated with the development of a series of structurally-associated compounds for cancer treatment, leading to the development of structural and functional cross-resistance (31). Despite the continuous introduction of novel chemotherapeutic agents, overcoming MDR remains a challenge in cancer chemotherapy $(32,33)$. Targeting cancer cell metabolism for cancer prevention and therapy is an emerging topic of research; compared with the majority of normal differentiated cells, cancer cells possess distinct metabolic requirements, including the production of energy primarily via glycolysis even in the presence of oxygen $(34,35)$. This phenomenon is known as the 'Warburg effect' and has received increasing 
attention since 2011 (36). Tumor cell metabolism results in the glycolysis-dependent production of cellular ATP due to mitochondrial dysfunction, hypoxia, tumor cell signal transduction or metabolic enzyme expression (37).

ABC transporters mediate cytotoxic drug active efflux and, following repeated chemotherapy cycles, cancer cells can develop MDR (38). Tumor cells proliferate rapidly and require numerous proteins, nucleic acids, lipids and ATP for their survival (39). Cancer cells are more dependent on the glycolytic pathway for ATP generation, compared with normal cells, and they eventually acquire drug resistance, typically due to the aberrant expression of drug-expelling ABC transporters (12). The ATP-dependence of drug transporters for activity $(40,41)$ suggests that glycolysis inhibition may increase the concentration of chemotherapeutic agents in cancer cells $(42,43)$. The most widely studied transporters, including MRP1, BCRP and $\mathrm{P}$-gp, are able to transport a variety of structurally-unassociated chemotherapeutic compounds from cancer cells, thereby inducing MDR (44).

Previous studies have suggested that certain chemicals isolated from Chinese medicinal herbs may exhibit antitumor activity by inducing the apoptosis of cancer cells $(16,17,45)$. Results from the present study demonstrated that SHK exerts antitumor effects by decreasing cell viability, inducing cell apoptosis and inhibiting ATP generation in A549 cells. The half-maximal inhibitory concentration of SHK in A549 cells, as determined using an MTT assay, has previously been determined to be $3.52 \pm 0.17 \mu \mathrm{g} / \mathrm{ml}$ (46). To confirm the effect of ATP reduction in A549 cells, the expression of MRP1, P-gp and BCRP was analyzed in the present study following combination treatment with SHK and AD. The results indicated that combination treatment with SHK and AD markedly decreased the expression of MRP1, P-gp and BCRP. Furthermore, SHK efficiently enhanced the cytotoxicity of AD against A549 cells by decreasing the levels of ATP, potentially leading to a decrease in activity of the ATP-dependent efflux pumps. The data from the present study suggest that SHK enhances the antitumor effect of AD through inhibiting ATP generation in A549 cells. These results indicate that the inhibition of glycolysis may be an effective therapeutic approach for the treatment of lung cancer.

In conclusion, the results of the present study collectively suggest that SHK may be a novel and attractive therapeutic candidate for tumor treatment in clinical practice. However, further studies are required in order to identify the precise molecular mechanisms underlying the effects of SHK in A549 cells.

\section{Acknowledgements}

The present study was funded by the National Key Clinical Specialist Construction Programs of China (grant no. 3101005005025).

\section{References}

1. Alberg AJ, Ford JG and Samet JM; American College of Chest Physicians: Epidemiology of lung cancer: ACCP evidence-based clinical practice guidelines (2nd edition). Chest 132 (3 Suppl): 29S-55S, 2007.

2. Baltayiannis $\mathrm{N}$, Chandrinos M,Anagnostopoulos D,Zarogoulidis $\mathrm{P}$, Tsakiridis K, Mpakas A, Machairiotis N, Katsikogiannis N, Kougioumtzi I, Courcoutsakis N and Zarogoulidis K: Lung cancer surgery: An up to date. J Thorac Dis 5 (Suppl 4): S425-S439, 2013.
3. Torre LA, Bray F, Siegel RL, Ferlay J, Lortet-Tieulent J and Jemal A: Global cancer statistics, 2012. CA Cancer J Clin 65: 87-108, 2015.

4. Wingo PA, Cardinez CJ, Landis SH, Greenlee RT, Ries LA, Anderson RN and Thun MJ: Long-term trends in cancer mortality in the United States, 1930-1998. Cancer 97 (12 Suppl): S3133-S3275, 2003.

5. Lynch TJ, Bell DW, Sordella R, Gurubhagavatula S, Okimoto RA, Brannigan BW, Harris PL, Haserlat SM, Supko JG, Haluska FG, et al: Activating mutations in the epidermal growth factor receptor underlying responsiveness of non-small cell lung cancer to gefitinib. N Engl J Med 350: 2129-2139, 2004.

6. Davies J, Patel M, Gridelli C, de Marinis F, Waterkamp D and McCusker ME: Real-world treatment patterns for patients receiving second-line and third-line treatment for advanced non-small cell lung cancer: A systematic review of recently published studies. PLoS One 12: e0175679, 2017.

7. Yoon SM, Shaikh T and Hallman M: Therapeutic management options for stage III non-small cell lung cancer. World J Clin Oncol 8: 1-20, 2017.

8. Galvani E, Peters GJ and Giovannetti E: EGF receptor-targeted therapy in non-small-cell lung cancer: Role of germline polymorphisms in outcome and toxicity. Future Oncol 8: 1015-1029, 2012.

9. Bach DH, Hong JY, Park HJ and Lee SK: The role of exosomes and miRNAs in drug-resistance of cancer cells. Int J Cancer 141: 220-230, 2017

10. Borst P, Evers R, Kool M and Wijnholds J: A family of drug transporters: The multidrug resistance-associated proteins. J Natl Cancer Inst 92: 1295-1302, 2000.

11. Allen JD and Schinkel AH: Multidrug resistance and pharmacological protection mediated by the breast cancer resistance protein (BCRP/ABCG2). Mol Cancer Ther 1: 427-434, 2002.

12. Oshikata A, Matsushita T and Ueoka R: Enhancement of drug efflux activity via MDR1 protein by spheroid culture of human hepatic cancer cells. J Biosci Bioeng 111: 590-593, 2011.

13. Joyce H, McCann A, Clynes M and Larkin A: Influence of multidrug resistance and drug transport proteins on chemotherapy drug metabolism. Exp Opin Drug Metab Toxicol 11: 795-809, 2015.

14. El-Sheikh AA, Morsy MA, Mahmoud MM and Rifaai RA: Protective mechanisms of coenzyme-Q10 may involve up-regulation of testicular P-glycoprotein in doxorubicin-induced toxicity. Environ Toxicol Pharmacol 37: 772-781, 2014.

15. Ponnusamy L, Mahalingaiah PKS and Singh KP: Treatment schedule and estrogen receptor-status influence acquisition of doxorubicin resistance in breast cancer cells. Eur J Pharm Sci 104: 424-433, 2017.

16. Wang CY, Bai XY and Wang CH: Traditional chinese medicine: A treasured natural resource of anticancer drug research and development. Am J Chin Med 42: 543-559, 2014.

17. Liu Z, Chen S, Cai J, Zhang E, Lan L, Zheng J, Liao L, Yang X, Zhou C and Du J: Traditional Chinese medicine syndrome-related herbal prescriptions in treatment of malignant tumors. J Tradit Chin Med 33: 19-26, 2013.

18. Han W, Li L, Qiu S, Lu Q, Pan Q, Gu Y, Luo J and Hu X: Shikonin circumvents cancer drug resistance by induction of a necroptotic death. Mol Cancer Ther 6: 1641-1649, 2007.

19. Yang H, Zhou P, Huang H, Chen D, Ma N, Cui QC, Shen S, Dong W, Zhang X, Lian W, et al: Shikonin exerts antitumor activity via proteasome inhibition and cell death induction in vitro and in vivo. Int J Cancer 124: 2450-2459, 2009.

20. Xuan Y and Hu X: Naturally-occurring shikonin analogues-a class of necroptotic inducers that circumvent cancer drug resistance. Cancer Lett 274: 233-242, 2009.

21. Bailly C: Topoisomerase I poisons and suppressors as anticancer drugs. Curr Med Chem 7: 39-58, 2000.

22. Nakaya K and Miyasaka T: A shikonin derivative, beta-hydroxyisovalerylshikonin, is an ATP-non-competitive inhibitor of protein tyrosine kinases. Anticancer Drugs 14: 683-693, 2003.

23. Kim SH, Kang IC, Yoon TJ, Park YM, Kang KS, Song GY and Ahn BZ: Antitumor activities of a newly synthesized shikonin derivative, 2-hyim-DMNQ-S-33. Cancer Lett 172: 171-175, 2001.

24. Chang IC, Huang YJ, Chiang TI, Yeh CW and Hsu LS: Shikonin induces apoptosis through reactive oxygen species/extracellular signal-regulated kinase pathway in osteosarcoma cells. Biol Pharm Bull 33: 816-824, 2010.

25. Long S, GuangZhi Y, BaoJie G, Wei X, YanYong H, YingLi W, Yang $\mathrm{Z}$ and LiHua L: Shikonin derivatives protect immune organs from damage and promote immune responses in vivo in tumour-bearing mice. Phytother Res 26: 26-33, 2012. 
26. Wu H, Xie J, Pan Q, Wang B, Hu D and Hu X: Anticancer agent shikonin is an incompetent inducer of cancer drug resistance. PLoS One 8: e52706, 2013.

27. EI Sayed SM, Mahmoud AA, EI Sawy SA, Abdelaal EA, Fouad AM, Yousif RS, Hashim MS, Hemdan SB, Kadry ZM, Abdelmoaty MA, et al: Warburg effect increases steady-state ROS condition in cancer cells through decreasing their antioxidant capacities (anticancer effects of 3-bromopyruvate through antagonizing Warburg effect). Med Hypotheses 81: 866-870, 2013 .

28. Carraro $\mathrm{M}$ and Bernardi P: Calcium and reactive oxygen species in regulation of the mitochondrial permeability transition and of programmed cell death in yeast. Cell Calcium 60: 102-107, 2016

29. Padmapriya R, Gayathri L, Ronsard L, Akbarsha MA and Raveendran R: In vitro anti-proliferative effect of tephrosia purpurea on human hepatocellular carcinoma cells. Pharmacogn Mag 13 (Suppl 1): S16-S21, 2017.

30. Falasca $M$ and Linton KJ: Investigational ABC transporter inhibitors. Expert Opin Invest Drugs 21: 657-666, 2012.

31. Joyce H, McCann A, Clynes M and Larkin A: Influence of multidrug resistance and drug transport proteins on chemotherapy drug metabolism. Expert Opin Drug Metab Toxicol 11: 795-809, 2015 .

32. Kathawala RJ, Gupta P, Ashby CR Jr and Chen ZS: The modulation of $\mathrm{ABC}$ transporter-mediated multidrug resistance in cancer: A review of the past decade. Drug Resist Updat 18: 1-17, 2015.

33. Pavan B, Paganetto G, Rossi D and Dalpiaz A: Multidrug resistance in cancer or inefficacy of neuroactive agents: Innovative strategies to inhibit or circumvent the active efflux transporters selectively. Drug Discov Today 19: 1563-1571, 2014.

34. Ponisovskiy MR: Warburg effect mechanism as the target for theoretical substantiation of a new potential cancer treatment. Crit Rev Eukaryot Gene Expr 21: 13-28, 2011.

35. Bayley JP and Devilee P: The Warburg effect in 2012. Curr Opin Oncol 24: 62-67, 2012.

36. Koppenol WH, Bounds PL and Dang CV: Otto Warburg's contributions to current concepts of cancer metabolism. Nat Rev Cancer 11: 325-337, 2011.

37. Sotgia F, Martinez-Outschoorn UE and Lisanti MP: Genetic induction of the Warburg effect inhibits tumor growth Oncotarget 3: 1266-1267, 2012.
38. Gottesman MM, Fojo T and Bates SE: Multidrug resistance in cancer: Role of ATP-dependent transporters. Nat Rev Cancer 2: 48-58, 2002.

39. Granchi $\mathrm{C}$ and Minutolo F: Anticancer agents that counteract tumor glycolysis. ChemMedChem 7: 1318-1350, 2012

40. Park S, Shimizu C, Shimoyama T, Takeda M, Ando M, Kohno T, Katsumata N, Kang YK, Nishio K and Fujiwara Y: Gene expression profiling of ATP-binding cassette (ABC) transporters as a predictor of the pathologic response to neoadjuvant chemotherapy in breast cancer patients. Breast Cancer Res Treat 99 9-17, 2006.

41. Kovalev AA, Tsvetaeva DA and Grudinskaja TV: Role of ABC-cassette transporters (MDR1, MRP1, BCRP) in the development of primary and acquired multiple drug resistance in patients with early and metastatic breast cancer. Exp Oncol 35: 287-290, 2013

42. Hou X, Huang F, Carboni JM, Flatten K, Asmann YW, Ten Eyck C, Nakanishi T, Tibodeau JD, Ross DD, Gottardis MM, et al: Drug efflux by breast cancer resistance protein is a mechanism of resistance to the benzimidazole insulin-like growth factor receptor/insulin receptor inhibitor, BMS-536924. Mol Cancer Ther 10: 117-125, 2011.

43. Nambaru PK, Hübner T, Köck K, Mews S, Grube M, Payen L, Guitton J, Sendler M, Jedlitschky G, Rimmbach C, et al: Drug efflux transporter multidrug resistance-associated protein 5 affects sensitivity of pancreatic cancer cell lines to the nucleoside anticancer drug 5-fluorouracil. Drug Metab Dispos 39: 132-139, 2011.

44. Schinkel AH and Jonker JW: Mammalian drug efflux transporters of the ATP binding cassette (ABC) family: An overview. Adv Drug Deliv Rev 55: 3-29, 2003.

45. Gao H, Lamusta J, Zhang WF, Salmonsen R, Liu Y, O'Connell E, Evans JE, Burstein S and Chen JJ: Tumor cell selective cytotoxicity and apoptosis induction by an herbal preparation from Brucea javanica. N Am J Med Sci (Boston) 4: 62-66, 2011.

46. Yeh YC, Liu TJ and Lai HC: Shikonin induces apoptosis, necrosis, and premature senescence of human A549 lung cancer cells through upregulation of p53 expression. Evid Based Complement Alternat Med 2015: 620383, 2015. 